This is a self-archived - parallel published version of this article in the publication archive of the University of Vaasa. It might differ from the original.

\title{
Analysis of photovoltaic technology development based on technology life cycle approach
}

Author(s): Jamali, Mahdis Yousef; Aslani, Alireza; Moghadam, Babak Farhang; Naaranoja, Marja; Madvar, Mohammad Dehghani

Title: Analysis of photovoltaic technology development based on technology life cycle approach

Year: $\quad 2016$

Version: Publisher's PDF

Copyright AIP Publishing, Creative Commons Attribution (CC BY) License

Please cite the original version:

Jamali, M. Y., Aslani, A., Moghadam, B. F., Naaranoja, M. \& Madvar, M. D., (2016). Analysis of photovoltaic technology development based on technology life cycle approach. Journal of Renewable and Sustainable Energy 8(3), 1-11. https://doi.org/10.1063/1.4952763 


\section{Analysis of photovoltaic technology development based on technology life cycle approach $\odot$}

Cite as: J. Renewable Sustainable Energy 8, 035905 (2016); https://doi.org/10.1063/1.4952763

Submitted: 25 September 2015. Accepted: 06 May 2016. Published Online: 27 May 2016

Mahdis Yousef Jamali (D), Alireza Aslani, Babak Farhang Moghadam (D), Marja Naaranoja, and Mohammad Dehghani Madvar

\section{COLLECTIONS}

EP This paper was selected as an Editor's Pick
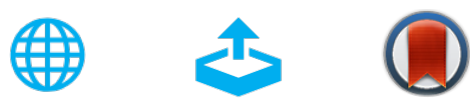

View Online

Export Citation

\section{ARTICLES YOU MAY BE INTERESTED IN}

Energy, exergy, and cost analyses of a double-glazed solar air heater using phase change material

Journal of Renewable and Sustainable Energy 8, 015101 (2016); https://

doi.org/10.1063/1.4940433

Electricity storage supporting PV competitiveness in a reliable and sustainable electric network

Journal of Renewable and Sustainable Energy 9, 012301 (2017); https://

doi.org/10.1063/1.4974851

Dye-sensitized solar cell scale-up: Influence of substrate resistance

Journal of Renewable and Sustainable Energy 8, 023704 (2016); https://

doi.org/10.1063/1.4944969

\section{AIP Author Services English Language Editing}




\title{
Analysis of photovoltaic technology development based on technology life cycle approach
}

\author{
Mahdis Yousef Jamali, ${ }^{1}$ Alireza Aslani, ${ }^{2,3, a)}$ Babak Farhang Moghadam, ${ }^{1}$ \\ Marja Naaranoja, ${ }^{3}$ and Mohammad Dehghani Madvar ${ }^{2}$ \\ ${ }^{1}$ Industrial Management Department, Institute of Management and Planning Researches, \\ Tehran, Iran \\ ${ }^{2}$ Renewable Energy Department, Faculty of New Science and Technology, \\ University of Tehran, Tehran, Iran \\ ${ }^{3}$ Industrial Management Department, Faculty of Technology, University of Vaasa, \\ Vaasa, Finland
}

(Received 25 September 2015; accepted 6 May 2016; published online 27 May 2016)

\begin{abstract}
Increasing energy demand has created the challenge of supplying safe, economical, and durable energy with minimal impact on the environment. Therefore, governments have developed and executed several strategies such as increasing efficiency in energy systems in addition to replacing existing sources with renewable energies. One of the most important renewable energy sources that have a competitive advantage compared with other resources is solar energy and its related technologies. However, development of this technology, its related products, and their competitiveness in the market has created a plethora of challenges. In this study, the focus is on the analysis of photovoltaic technology development in the context of different technology generations. The S-shape curve of each generation and sub-technologies of photovoltaic is designed and analyzed. Results show that the first generation of photovoltaic technology is in growth and early maturity stage. The second generation is also in growth stage, but the third generation is mainly in the introduction stage. Published by AIP Publishing. [http://dx.doi.org/10.1063/1.4952763]
\end{abstract}

\section{INTRODUCTION}

Global demand for energy is increasing. To effectively meet future energy demand, security and reliability of energy should be improved and alternative energy sources should be developed. An effective way to meet this demand is the utilization of renewable energy sources. Developing and using renewable energy sources can increase diversity of energy sources in the energy markets. ${ }^{1}$

Among the renewable energy sources to be exploited on a commercial scale, solar energy has an important role. ${ }^{2}$ According to research, solar energy has a potential to supply whole human energy needs in the world. This source is useable via technologies such as photovoltaic panels (PV), concentrating solar thermal power (CSP), and concentrated photovoltaic (CPV). ${ }^{3}$

Despite the importance of solar energy utilization, the development of products and technologies related to this energy comes with many challenges. The challenges are mostly related to the complexity and efficiency of the utilization of the technologies. ${ }^{17,18}$ However, development of new solar technologies and products has grown faster in recent years, leading to a shorter life cycle for older technologies, difficulty for older technologies to maintain market share and less product success in the market. Therefore, due to the high competitiveness of solar technology alternatives, such as fossil fuels and alternative renewable, the success of the solar products and their position in the markets have faced challenges. ${ }^{4}$

\footnotetext{
a) Author to whom correspondence should be addressed. Electronic mail: alireza.aslani@ut.ac.ir. Tel./Fax: +358 44255 0010.
} 
One of the important solar energy utilization technologies is photovoltaic. This technology is divided into different generations and sub-technologies. This research focuses on monitoring and analyzing photovoltaic technologies based on the Technology Life Cycle (TLC) approach. This approach helps the researchers to understand the technology development trends and predict the future of the technologies and sub-areas. The diagrams are based on the patent analysis registered in the international patent organizations. The patent trends show how a technology is growing or declining. It helps policy makers allocate their budgets and priorities on research with high efficiency and based on market demand.

The work starts with an overview on the importance of renewable energy sources and technologies. Subsequently, the concept of product development and technology life cycle is reviewed, followed by the introduction of the main technologies of each photovoltaic generation. Finally, by using the patent analysis method, the status of each photovoltaic technology generation is analyzed and the future of the technologies is drawn.

\section{LITERATURE REVIEW}

\section{A. Importance of energy and renewable sources}

Energy is an important factor for achieving economic development and social welfare. ${ }^{5}$ Fossil fuels still cover more than $80 \%$ of the world primary energy supply. Increase in energy prices, volatility and uncertainty in supplying energy, and political factors are some of the challenges that increase the risks of energy security. ${ }^{19}$ Utilization of alternative renewable energy sources is one of the solutions to maintaining competitive advantage and economic growth, while ensuring energy supply and improving economic and environmental sustainability. ${ }^{6,20}$

The potential of renewable energy sources is enormous and can meet the world energy demand. Due to the limitations, supply risks, and environmental effects of fossil fuels, the utilization of renewable energy technologies, in particular, sources such as solar and wind power have been the subject of much interest within governments and policy makers. Given the developments of renewable energy technologies, the market opportunities of renewable energy products and services have been rapidly increasing and the advantages have been established for emerging renewable energy markets.

\section{B. Overview of the photovoltaic technology}

Two of the main solar energy technologies are CSP (Concentrated Solar Panels) and PV (photovoltaic solar cells). The focus of this research is photovoltaic technology. Photovoltaic panels (PV) are the devices that directly convert solar radiation into electricity using the photovoltaic effect. ${ }^{3}$

Based on the European Photovoltaic Industry Association (EPIA), solar PV systems capacity will reach $688 \mathrm{GW}$ by 2020 with annual investment worth $620 \times 10^{9}$ euros between now and 2020. It is a technology that over a billion people will use and $3.62 \times 10^{6}$ job opportunities will be created until 2020. The global capacity of solar PV facilities was around $16.5 \mathrm{GW}$ in 2010. The International Energy Agency (IEA) expects solar energy to supply $11 \%$ of global electricity and $20 \%$ of global energy by 2050 . This means solar energy plays an important role in the future of energy, so it would be the first choice for the governments and private companies in the solar-rich countries. ${ }^{7}$

From a technological perspective, PV is divided into three generations: the first generation of solar cell technology which is fully commercialized. It is the technology of crystalline silicon (c-si) semiconductors used in both single crystal (sc-si) and multi-crystalline (mc-si). Single crystals are typically used and hold about $80 \%$ of the PV market. Maximum efficiency of mono crystalline silicon solar cells under standard conditions is about $23 \%$, but the highest efficiency recorded was $24.7 \%$.Due to the high cost of single crystalline production, manufacturers turned to multi-crystalline cell. Semiconductor polycrystalline silicon (pc-si) is a good material to reduce the cost of solar cells that are being developed. However, its efficiency compared to single-crystal cells and other developing materials is less. 
The second generation of solar cells that currently has been expanded on the market is based on a "thin layer" solar cell technology. It has three main types: (1) amorphous (a-si) and micromorph silicon (a-si/ $\mu \mathrm{c}$-si), (2) cadmium telluride (CdTe), (3) copper-indium-Selenide (CIS) and copper indium gallium di selenide (CIGS).

Compared with silicon solar cells, thin-film technology is less expensive because of the materials and the manufacturing process. The biggest challenge for CIGS modules is the limited ability to scale up the process for high throughput and high-performance. In addition to first and second generations of solar cell technologies, emerging methods have been introduced in the manufacture of solar cells. ${ }^{8}$ PV technologies that have been made by many countries include equipment manufacturers, cell manufacturers, panel's builders, and installers. According to the annual survey by market PV trade magazine, Photon International, the global production of cells and PV modules on 2009 was $12.3 \mathrm{GW}, 45 \%$ of this amount was made by the top 10 leading companies: First Solar, Suntech Power, Sharp, Q-Cells, Yingly Green Energy, JA Solar, Kyosera, Trina Solar, Sunpower, and Gintech. ${ }^{1}$

\section{Technology life cycle and product development}

The concept of the technology life cycle (TLC) and product planning was created between 1960 and 1970 with the aim of providing technology strategy and products. Generally, the technology/product life cycle consists of four stages: introduction, development, maturity, and decline (Figure 1). The concept of technology life cycle from a marketing point of view has been created in order to define the best strategy for the development of technology and related activities associated with the development of products that have a special place in the market and among customers. ${ }^{4}$

To estimate the future development of a technology and evaluating investment decisions, understanding the current stage and trends of TLC is beneficial. The prevailing approach to the analysis of the TLC is the S-curve which observes patent applications made over time. Economic environment that is rapidly changing and is under fierce competition needs innovative companies, both in terms of products as well as marketing strategies. Successful products should have a balance between three elements: technology, marketing, and user experience. Technology plays a key role among these three components. Before developing the product strategy, technology strategy should be established to offer competitive products, materials, processes, and technology systems. The first step in establishing a technology strategy is to decide whether the technology is worth the investment or not. How would the technology development be in future? Will technology progress in the future or drop? To answer these questions, understanding the current technology life cycle stage in order to estimate its future development trends is important. ${ }^{9-14}$

The normal trend of technology advancement is at first slow, then it accelerates, and then it declines. As a result, it looks like the shape of the curve which shows some steps such as "introduction," "growth," "maturity," and "aging." In another approach, it can be a change in

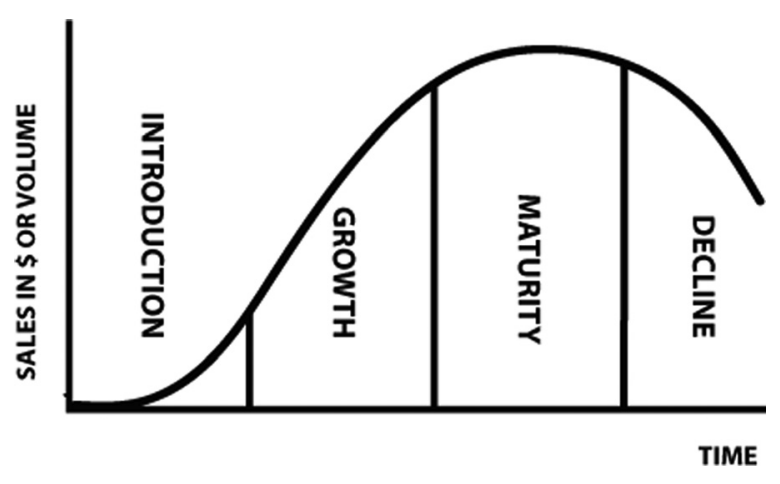

FIG. 1. Life cycle curve. 
design or improvement of technologies used over time. The progress in the early stages where industry has faced with uncertainty is slow and gets faster when obstacles are overcome. Accordingly, for the simplest products, taking a TLC that represents all technological progresses related to specific synthetic is impossible, and for this reason, the concept of technology life cycle should focus on the technology applications where each synthetic or product is used. ${ }^{15,16}$

To estimate the future development of a technology, and decide on an investment, the situation of technology in the life cycle should be identified. The dominant approach to analyze the technology life cycle is the use of S-shaped curve and patent evaluation of a technology over time. ${ }^{9}$

\section{RESEARCH METHODS}

This study is to identify progress and future of PV technologies by using a technology life cycle approach. Figure 2 shows the research steps. First, the researchers determine "Technology Target Area." Target area is a key area where the researchers are looking for technology life curve. In this study, the technology target area is solar cell (PV). Then, based on a survey, primary keywords of PV technologies and generations are identified for searching patents.

In order to provide a technology life-cycle curve of PV, the data related to patents are extracted and analyzed. The time span is from 1970 until the end of August 2015. Search results by keywords are number patents and codes and information about them. With further search among patents and various keywords, a number of repetitive codes are acquired. The search of patents are verified via CPC codes and screening the codes to get to key codes. After

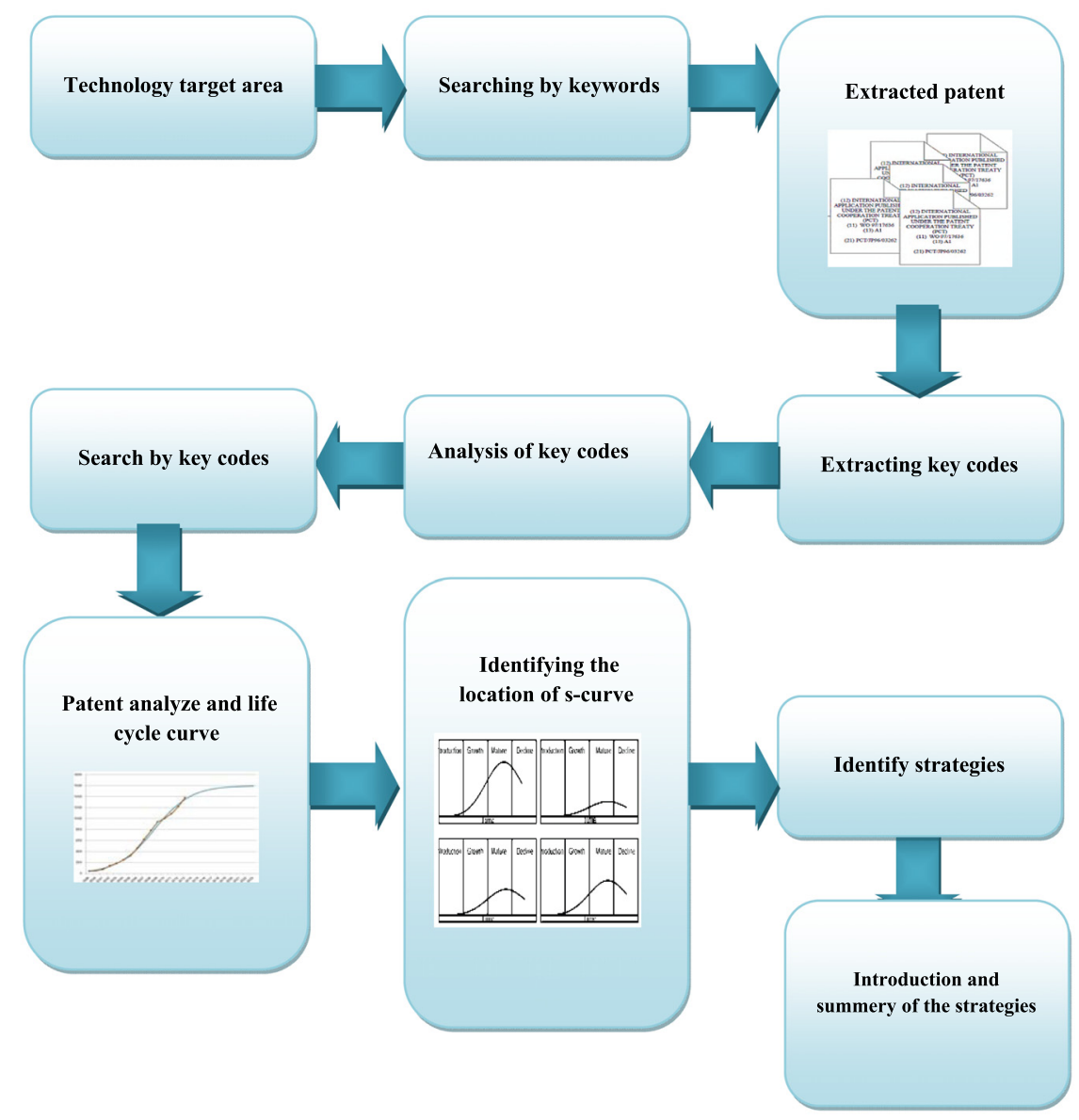

FIG. 2. Research steps. 
TABLE I. Photovoltaic codes, descriptions, and generations.

\begin{tabular}{lcc}
\hline \hline Source code & Description & Generation \\
\hline Y02E 10/541 & CuInSe $_{2}$ material PV cells & Generation 2 \\
Y02E 10/542 & Dye sensitized solar cells & Generation 3 \\
Y02E 10/543 & Solar cells from Group II-VI materials & Generation 2 \\
Y02E 10/544 & Solar cells from Group III-V materials & Generation 2 \\
Y02E 10/545 & Microcrystalline silicon PV cells & Generation 1 \\
Y02E 10/546 & Polycrystalline silicon PV cells & Generation 1 \\
Y02E 10/547 & Mono crystalline silicon PV cells & Generation 1 \\
Y02E 10/548 & Amorphous silicon PV cells & Generation 2 \\
Y02E 10/549 & Organic PV cells & Generation 3 \\
\hline \hline
\end{tabular}

extracting the codes and patent numbers in each sub-technology and generation, the S-curves are drawn. This is followed by the analysis and results.

\section{ANALYSIS}

According to the research steps explained in Sec. III, the main codes of PV technologies, their descriptions, and generations are shown in Table I.

After that, patent status and curve are shown. The researchers put these curves in accordance with the S-curve.

\section{A. Solar cells first generation}

The first generation of solar cells contains silicon. Silicon is one of the most common elements on Earth. This element is a semiconductor, suitable for use in photovoltaic systems. Crystalline silicon cells are divided into different categories: mono-crystal silicon and polycrystalline silicon. Other crystalline cell categories contain gallium arsenide. Registered patents in the field of microcrystalline are shown in Figure 3.

Most of the micro-crystal silicon patents were registered in 2011 (around 270 patents). In fact, between 1980 and 2007 patenting on this technology had fluctuations, but then from 2007 to 2011, the number of patents has been growing, which can be partially attributed to the changes in oil prices. Thus, the cost of $R \& D$ for photovoltaic technology considered affordable. After 2011, patenting is reduced according to the number of patents registered in other two types of first-generation solar cells. This decline might be due to the emergence of new technologies. By comparing two charts, we can predict the technology life cycle. Graph technology life cycle consists of four main sections: "birth," "growth," "maturity," and "decline." From 1977 to 2000, the technology was at the birth or appearance. It is expected that the technology began growth in 2000. This stage is when the technology has the potential in industrial and commercial use. The year 2011 is a point of efficiency for this technology.
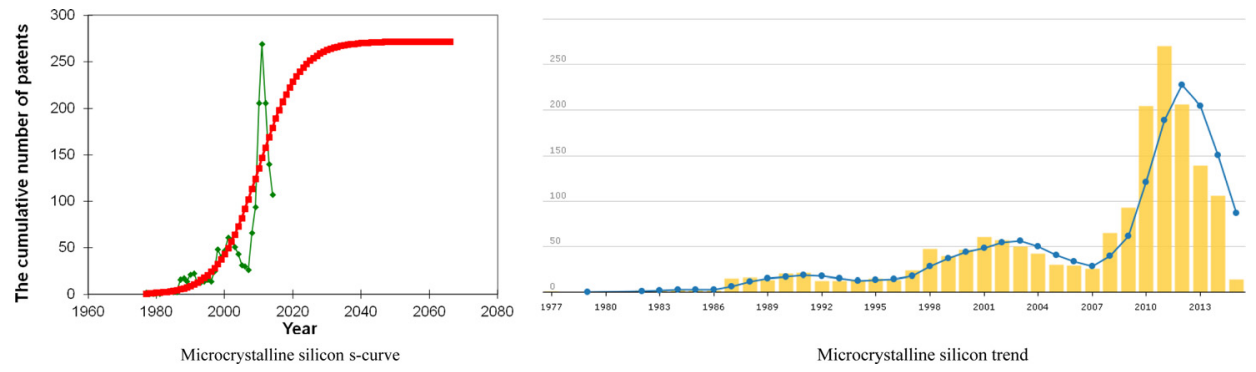

FIG. 3. Microcrystalline silicon graphs. 

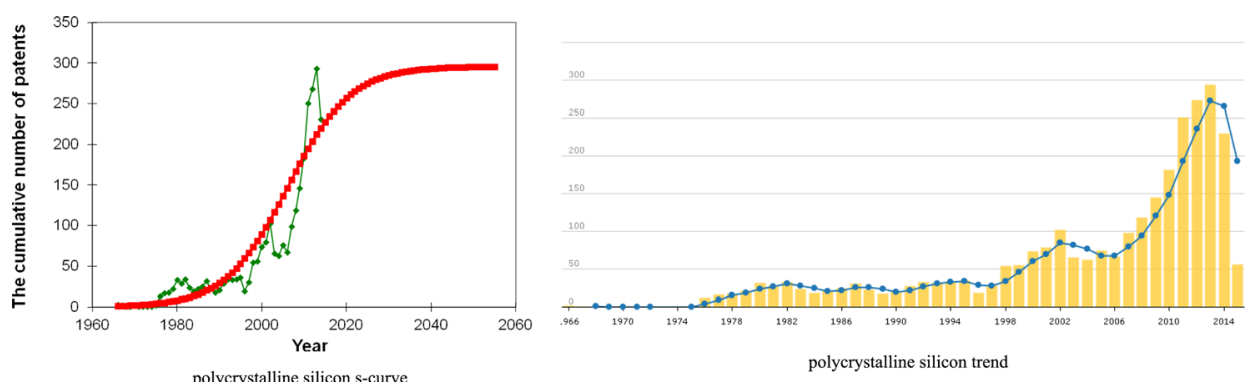

FIG. 4. Patents of polycrystalline silicon.

Efficiency point is the point where the cost of production is economic for all beneficiaries. After productivity point of technology, maturation stage begins. At this stage, no major changes will occur in technology and changes will be limited to optimizations done by the industry itself. At this stage of technology life span, literatures and patents reduced in exchange for increasing trademarks and companies that are established in relation to the technology. When the curve is horizontal, the maturity level is completed. It seems that maturity for this technology will be completed in 2030. After the point of maturity, depending on the type of technology, it will enter the decline step. According to the position of micro-crystal silicon, and remaining years to complete the maturity of this technology, business environment of this industry continues to be favorable for product development and related technology companies. Figure 4 shows the patents in the field of polycrystalline silicon, which is the category placed in the first generation.

Polycrystalline silicon technology patenting trend has begun since early 1966. There have been large swings in the field of patenting for this technology between 1996 and 2006 that is partially attributed to the fluctuations in oil price over the years. From 2006 to 2013, the number of patents of this technology has grown. The highest number of patenting of this technology was in 2013 and has about 294 patents that almost double the amount of recorded patents in the micro-crystal technology for that year. This may be due to an unprecedented increase in oil prices between 2011 and 2013. By comparing the results of two graphs, polycrystalline silicon technology between 1966 and 1989 was in the emergence stage. Then, it began to grow until 2013, by reaching its point of efficiency. After 2013, the number of registered patents was reduced. After the point of efficiency 2013, technology maturation phase begins and is completed by 2030. According to the position of polycrystalline silicon, and remaining years to complete maturity of this technology, business environment of this industry continues to be favorable for product development and related technology companies.

Figure 5 shows the trend of silicon single crystal patents which placed in the category of first generation.

Given the number of single-crystalline silicon technology patent, this technology had most of its registered patents in 2013 which has been about 1809 patents. This patent is much more than the other two types of generation in 2013. The number of registered patents in this technology was stable until 2007 and then from 2007 to 2013 had significant growth.

Comparing the two graphs showing that single-crystal technology was in the process of emergence during 1966 to 1990, and then it entered into its growth phase. During the growth phase, patenting had a significant increase. It reached the point of efficiency in 2013. Technology maturation stage started after the point of efficiency and maturity will be completed around 2030. According to this process, business environment of this industry for product development and related technology companies can be favorable.

As seen in Figure 5, most of the trends in patents relating to the first generation have frequencies during different periods, which indicate that in recent years other emerging technologies have been introduced and the technology direction has changed (e.g., organic solar cells). 

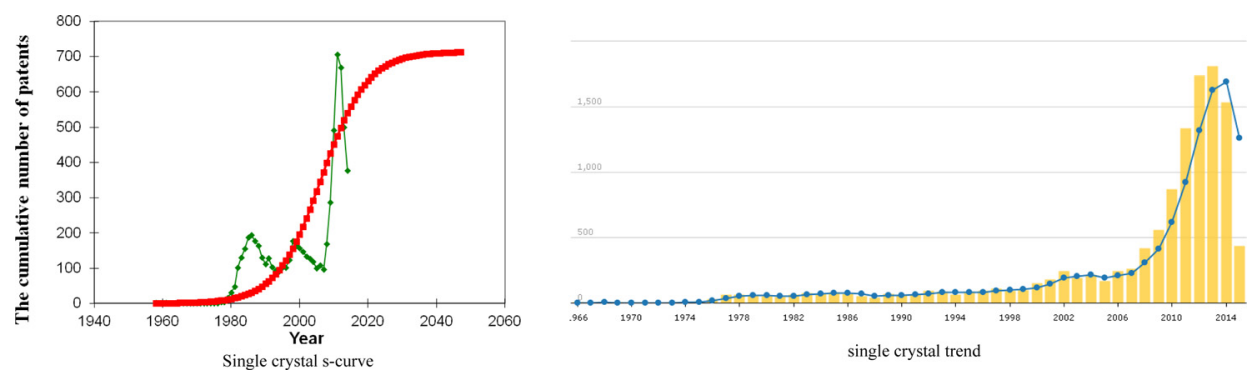

FIG. 5. Patents of silicon single crystal.

\section{B. Second solar cells generation}

Thin-film solar cell (TFSC), also called thin film photovoltaic cell (TFPV), is the second generation of solar cells. This technology is used in photovoltaic systems integrated with building materials as well as semi-transparent photovoltaic glass used to cover windows. In other commercial uses, thin-film cells are placed between two glass plates, and the solar panels are used on some of the largest photovoltaic power plants in the world (Fig. 6).

Amorphous silicon technology patenting trend begun since 1977. Since 1980, it faced with an annual increase in patents, but in the meantime had fluctuations. From 2007 to 2012, patenting has grown considerably, so it reached its highest value in 2011. This technology steps in the emergence between 1977 and about 1980, the number of patents registered in this year has been reduced. After 1980 entered growth stage; 2011 was point efficiency for this technology, which then entered the maturity stage and completed maturity until about 2030. According to this process, business environment of this industry for product development and related technology companies can continue to be favorable.

Figure 7 shows the patents in the field of $\mathrm{CuInSe}_{2}$ which has been classified as the second generation.

The number of patent applications for this technology was low during 1996-2004. It made significant growth during 2004-2014. Most registered patents for this technology happened in 2013 (1239 patents). This technology was in process of emergence during 1962-1991. During those years, the number of patents was not considerable. Then, it entered to its growth stage, from 1991 number of patents increased until to the point where the desired technology will offer using a new products or services. Figure 8 shows semiconductor II-VI groups.

The number of registered patents for semiconductor II-VI technology had relatively stable trend with little fluctuation during 1966-2008. However, it had a significant growth from 2008 to 2012. After 2012, the number of patents was again reduced. Semiconductor II-VI technology was in the introduction phase during 1953-1976. From 1976 until 2012, it reached the efficiency point and moved to its growth stage. After spending the point of efficiency, maturity stage begins and by 2042 maturity will be completed. According to the predictions and in terms of investment, this technology is more favorable for product development because of more
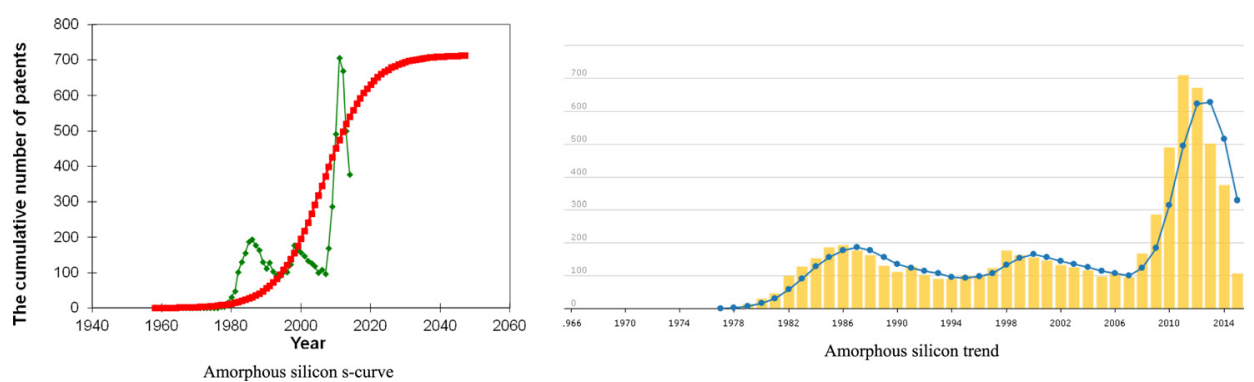

FIG. 6. Patents curve of amorphous silicon. 

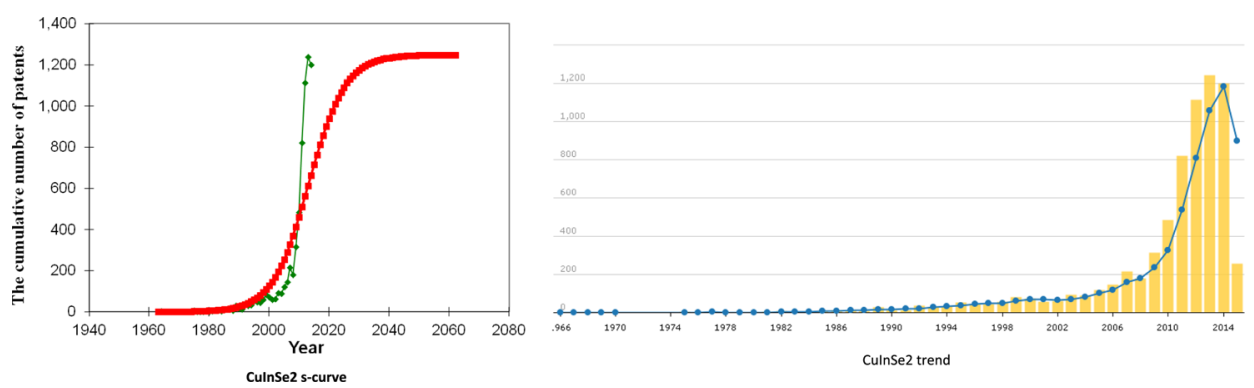

FIG. 7. Patents curve of CuInSe2.
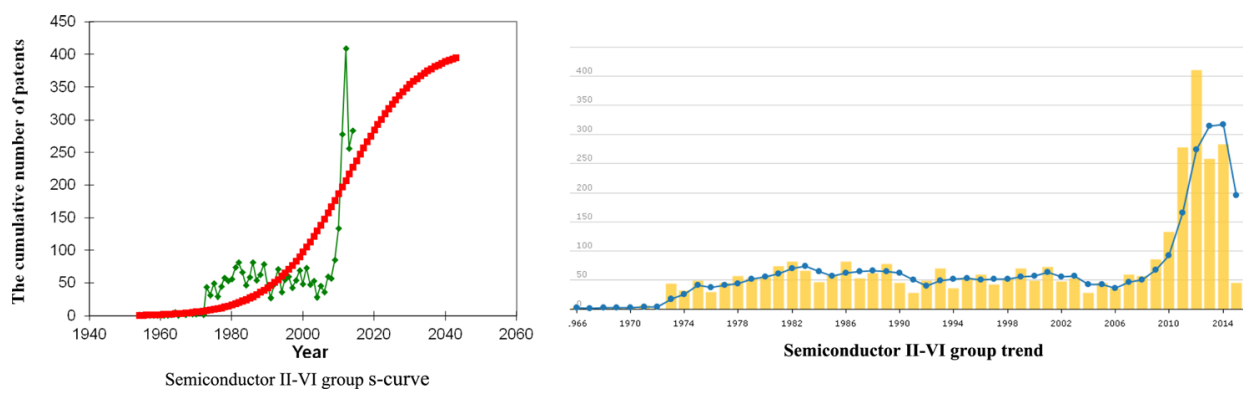

FIG. 8. Patents curve of semiconductor II-VI group.

period of time necessary to complete its maturation. Figure 9 shows the patents in the field of semiconductor III-V group.

By comparing the charts, semiconductor III-V technology life cycle stages are as follows, from 1958 to about 1980, it was in the introduction stage. From 1980 to 2013, it spent the growth stage and it reached to the point of efficiency in 2013. After that, the maturation process begins and will be completed in 2035. The decline of this technology depending on the circumstances may occur in the following years.

Given the number of patents registered in the second-generation technologies, as well as its comparison with the first generation, researchers have less interest on these technologies and they still did not reach their full maturity. The main reason for that is low efficiency of second generation solar cells.

\section{Third generation of photovoltaic technologies}

Third generation technologies of PV are divided into the following categories: CPV, organic solar cells, dye-sensitized solar cells, polymer solar cells, and solar cells based on liquid crystals.
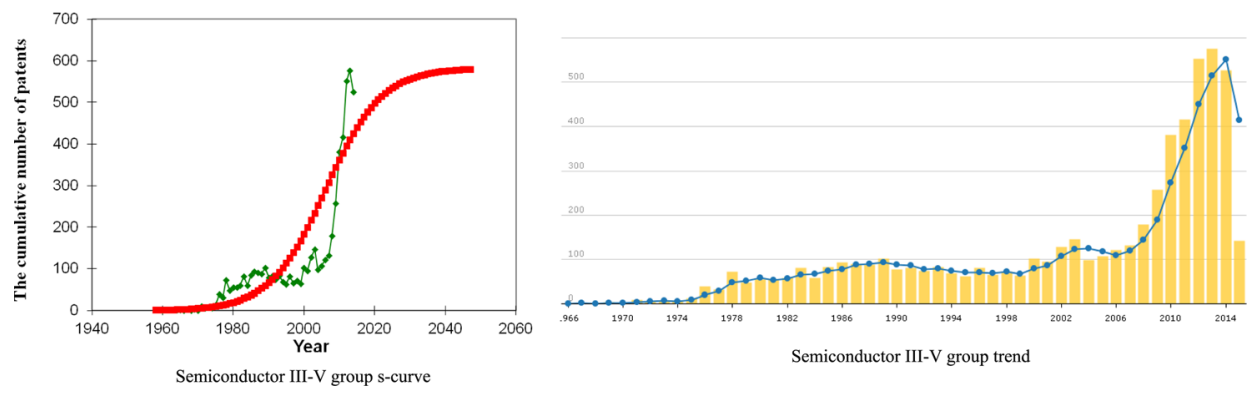

FIG. 9. Patents curve of semiconductor III-V group. 

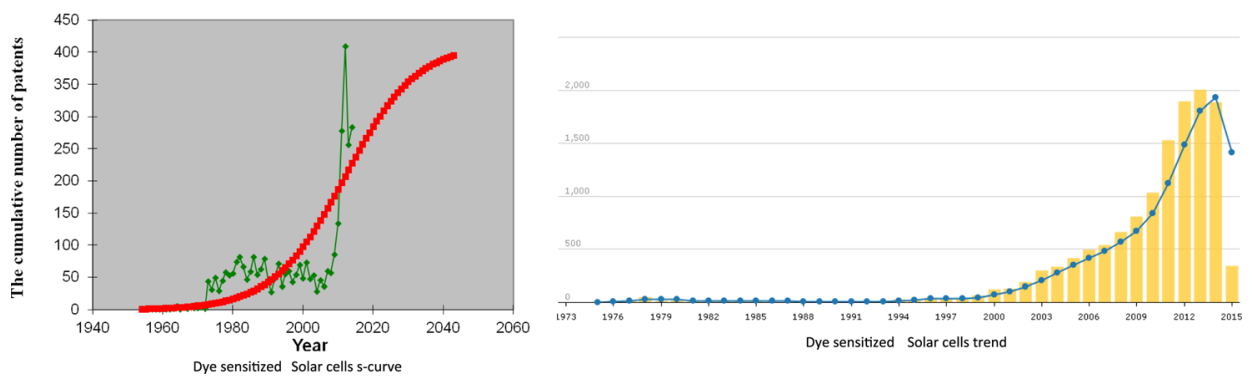

FIG. 10. Patents curve of third generation.

Figure 10 shows a stable technology development increase until 2000. In fact, the number of registered patents in these technologies from the beginning to the end of the graph is rising. The largest number of patents in these technologies was recorded in 2013. Dye sensitized technologies were in the introduction stage from 1954 to 1986. It passed the development stage and reached the efficiency point in 2012. Maturity of this technology will occur around 2042. After that, depending on the circumstances may face decline (Fig. 11).

Organic technologies, as well as other types of group III, in terms of patent applications are developing. The process of patenting for this technology began to increase significantly in 2003 and has achieved the highest value in 2014 (4147 patents). Organic group technologies were in the introduction stage between 1959 and 1996, then they entered the growth stage. The efficiency point for these technologies occurred in 2014 and full maturity will be in 2040 .

\section{SUMMARY AND CONCLUSION}

Energy is the main input for products/services, increasing world population and energy demand, as well as shortage of fossil fuel sources brought replacement strategies such as renewable energy utilization. One of the important renewable energy sources is solar energy and its main technologies, photovoltaic. This research focused on the trend of photovoltaic technologies development by considering its different generations. The results of technological curve analysis show that overall industries are growing in all three main generations of photovoltaic technologies. By searching studied technologies patents, life cycle diagram, and their S-curve, the researchers found that the technologies associated with solar cells are generally located at their early stage of development and maturity. This shows that the markets related to these technologies are expanding, which shows more promises in growth of the technology markets. Figures 12 and 13 are the cumulative patent analysis and S-curve of the photovoltaic technologies. The cumulative diagram is the sum of technologies that we reviewed in Secs. I-IV.

Overall, photovoltaic technologies spent their growth stage. In particular, the first generation of photovoltaic technology is in growth and early maturity stages. The second generation is also in the growth stage and the third generation is in the introduction and growth stages.
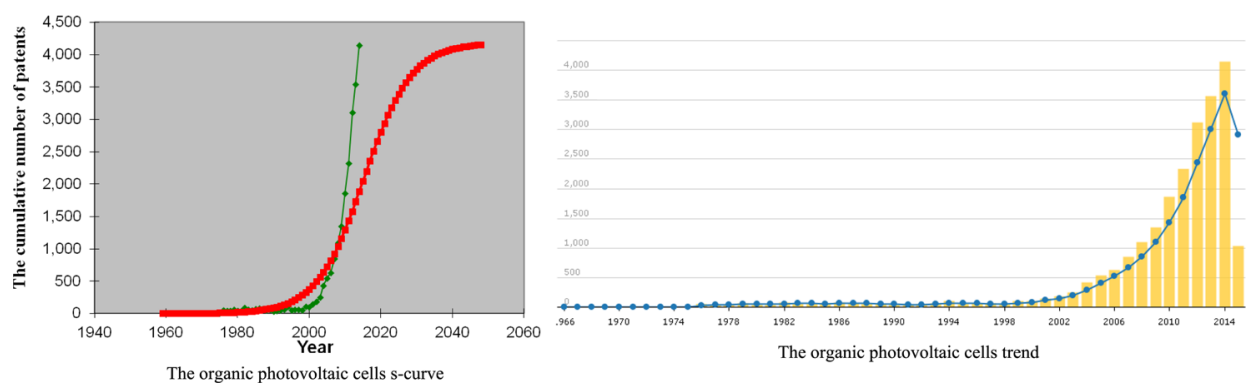

FIG. 11. Patents curve of organic photovoltaic cells. 


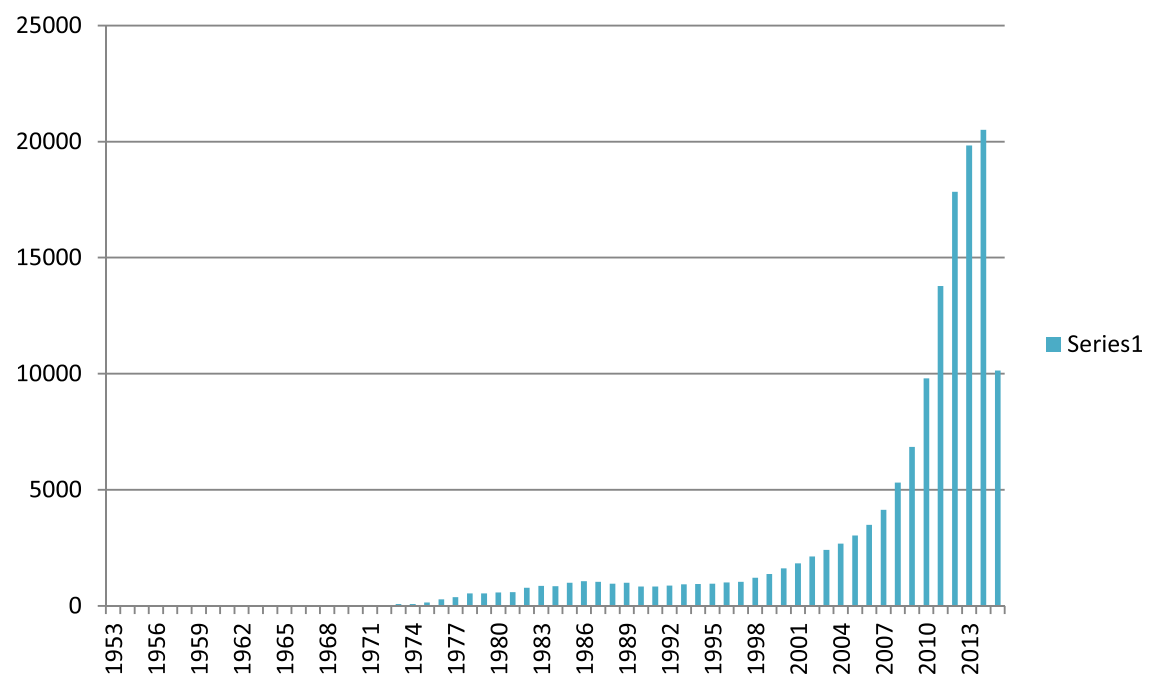

FIG. 12. Total cumulative patents of photovoltaic technologies.

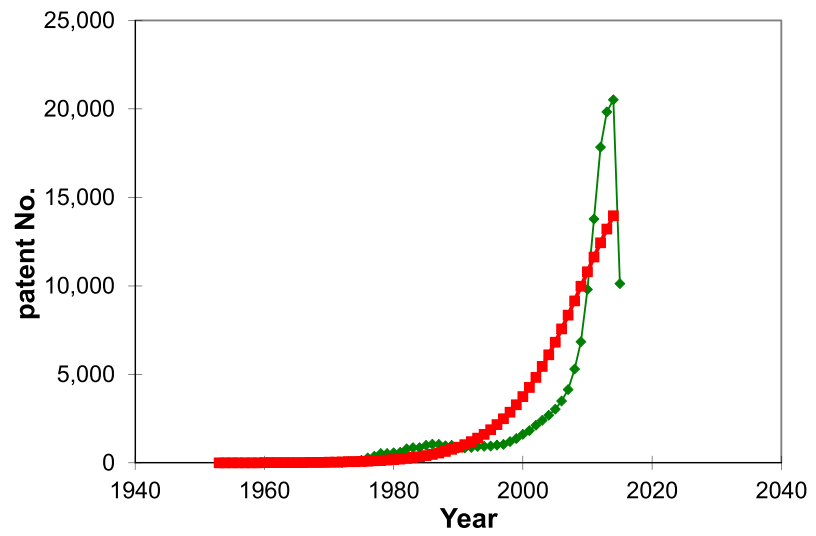

FIG. 13. Cumulative s curve of photovoltaic technologies.

This research is one of the first to study the PV technology trends from their generations and sub-technologies. Several researches can be suggested for future, like identification and analysis of the effective factors of PV technologies in each generation. Indeed, the approach can be implemented for other sources and technologies. The efficiency and allocation of R\&D funds for PV technology development can be also studied for future researches. Finally, designing a roadmap for the development of these technologies and their future study can be also recommended for future research.

${ }^{1}$ V. Devabhaktuni, M. Alam, S. S. S. R. Depuru, R. C. Green, D. Nims, and C. Near, "Solar energy: Trends and enabling technologies," Renewable Sustainable Energy Rev. 19, 555-564 (2013).

${ }^{2}$ H. A. De Beijer, "Product development in solar water heating," Renewable Energy 15(1), 201-204 (1998).

${ }^{3}$ R. Ferry and E. Monoian, A Field Guide to Renewable Energy Technologies, 1st ed. (Society for Cultural Exchange, 2012).

${ }^{4}$ H. Gmelin and S. Seuring, "Determinants of a sustainable new product development," J. Cleaner Prod. 69, 1-9 (2014).

${ }^{5}$ F. Al-Mansour, B. Sucic, and M. Pusnik, "Challenges and prospects of electricity production from renewable energy sources in Slovenia," Energy 77, 73-81 (2014).

${ }^{6}$ F. J. Sáez-Martínez, J. Mondéjar-Jiménez, and J. A. Mondéjar-Jiménez, "The energy challenge: Energy and environment knowledge week E2KW 2013," J. Cleaner Prod. 86, 471-473 (2015).

${ }^{7}$ S. Y. Liu, Y. H. Perng, and Y. F. Ho, "The effect of renewable energy application on Taiwan buildings: What are the challenges and strategies for solar energy exploitation?," Renewable Sustainable Energy Rev. 28, 92-106 (2013).

${ }^{8}$ Z. Abdin, M. A. Alim, R. Saidur, M. R. Islam, W. Rashmi, S. Mekhilef, and A. Wadi, "Solar energy harvesting with the application of nanotechnology," Renewable Sustainable Energy Rev. 26, 837-852 (2013). 
${ }^{9}$ L. Gao, A. L. Porter, J. Wang, S. Fang, X. Zhang, T. Ma, and L. Huang, "Technology life cycle analysis method based on patent documents," Technol. Forecasting Soc. Change 80(3), 398-407 (2013).

${ }^{10}$ A. Griffin, "PDMA research on new product development practices: Updating trends and benchmarking best practices," J. Prod. Innovation Manage. 14(6), 429-458 (1997).

${ }^{11}$ P. Kotler, Marketing Management: Analysis, Planning, Implementation, and Control (Englewood Cliffs, Prentice-Hall, NJ, 1988).

${ }^{12}$ M. Ilori, J. Oke, and S. Sanni, "Management of new product development in selected food companies in Nigeria," Technovation 20, 333-342 (2000).

${ }^{13}$ P. Kotler and G. Armstrong, Principle of Marketing (Prentice Hall, Europe, 2013).

${ }^{14}$ K. B. Clark, W. B. Chew, T. Fujimoto, J. Meyer, and F. M. Scherer, "Product development in the world auto industry," in Brookings Papers on Economic Activity (Harvard Business Press, 1987), pp. 729-781.

${ }^{15}$ M. Taylor and A. Taylor, “The technology life cycle: Conceptualization and managerial implications," Int. J. Prod. Econ. 140(1), 541-553 (2012).

${ }^{16}$ A. A. Techatassanasoontorn and R. J. Kauffman, "Examining the growth of digital wireless phone technology: A take-off theory analysis," Decis. Support Syst. 58, 53-67 (2014).

${ }^{17}$ A. Aslani, "Strategic variables of commercialization of renewable energy technologies," J. Renewable Sustainable Energy 7, 023105 (2015).

${ }^{18}$ IEA, Energy Statistics (IEA, 2015).

${ }^{19}$ A. Aslani, M. Naaranoja, and A. Mohaghar, Renewable Energy Industry: Business Aspects, Encyclopedia of Energy Engineering and Technology, 2nd ed. (Taylor and Francis, 2015).

${ }^{20}$ A. Aslani, E. Antila, and K. F. V. Wong, "Comparative analysis of energy security in the Nordic countries: The role of renewable energy resources in diversification,” J. Renewable Sustainable Energy 4(6), 062701 (2012). 